\title{
Bystander T cells in human immune responses to dengue antigens
}

\author{
Duangchan Suwannasaen, Arunrat Romphruk, Chanvit Leelayuwat, Ganjana Lertmemongkolchai*
}

\begin{abstract}
Background: Previous studies of T cell activation in dengue infection have focused on restriction of specific T cell receptors (TCRs) and classical MHC molecules. However, bystander T cell activation, which is TCR independent, occurs via cytokines in other viral infections, both in vitro and in vivo, and enables $T$ cells to bypass certain control checkpoints. Moreover, clinical and pathological evidence has pointed to cytokines as the mediators of dengue disease severity. Therefore, we investigated bystander T cell induction by dengue viral antigen.

Results: Whole blood samples from 55 Thai schoolchildren aged 13-14 years were assayed for in vitro interferongamma (IFN- $\gamma$ ) induction in response to inactivated dengue serotype 2 antigen (Den2). The contribution of TCRdependent and independent pathways was tested by treatment with cyclosporin A (CsA), which inhibits TCRdependent activation of T cells. ELISA results revealed that approximately $72 \%$ of IFN- $\gamma$ production occurred via the TCR-dependent pathway. The major IFN- $\gamma$ sources were natural killer (NK) (mean \pm SE $=55.2 \pm 3.3$ ), CD4 ${ }^{+} \mathrm{T}(24.5 \pm$ 3.3) and $C D 8^{+} T$ cells $(17.9 \pm 1.5)$, respectively, as demonstrated by four-color flow cytometry. Interestingly, in addition to these cells, we found CSA-resistant IFN- $\gamma$ producing T cells $\left(C D 4^{+} T=26.9 \pm 3.6 \%\right.$ and $C D 8^{+} T=20.3 \pm$ $2.1 \%)$ implying the existence of activated bystander $\mathrm{T}$ cells in response to dengue antigen in vitro. These bystander $\mathrm{CD}^{+}$and $\mathrm{CD} 8^{+} \mathrm{T}$ cells had similar kinetics to NK cells, appeared after $12 \mathrm{~h}$ and were inhibited by anti-IL-12 neutralization indicating cytokine involvement.

Conclusions: This study described immune cell profiles and highlighted bystander $T$ cell activation in response to dengue viral antigens of healthy people in an endemic area. Further studies on bystander T cell activation in dengue viral infection may reveal the immune mechanisms that protect or enhance pathogenesis of secondary dengue infection.
\end{abstract}

\section{Background}

$\mathrm{T}$ cell mediated production of cytokines, such as TNFalpha, interferon-gamma (IFN- $\gamma$ ) and interleukin (IL)10 , has been reported to influence the severity of dengue infection [1-5]. The mechanisms of $\mathrm{T}$ cell activation are mostly focused on the classical pathway, that is activation via binding of specific $\mathrm{T}$ cell receptors (TCRs) and MHC molecules [6,7]. However, T cells may also be activated after stimulation by 'bystander' or TCRindependent signaling, for example by cytokines or novel activating receptors [8-12]. Bystander T cell activation has been demonstrated in models of viral infection such as herpes simplex virus, LCMV and HIV

\footnotetext{
* Correspondence: ganja_le@kku.ac.th
The Centre for Research and Development of Medical Diagnostic

* Correspondence: ganja_le@kku.ac.th
The Centre for Research and Development of Medical Diagnostic Laboratories, Faculty of Associated Medical Sciences, Khon Kaen University, Khon Kaen, Thailand
}

leading to proliferation of memory $\mathrm{T}$ cells and subsequent production of cytokines, which can induce protection or pathology $[9,11,13]$. In addition to virus infection, our studies have identified IFN- $\gamma$ producing bystander $\mathrm{CD}^{+} \mathrm{T}$ cells in response to intracellular bacteria and showed that these $\mathrm{T}$ cells produced IFN- $\gamma$ within $24 \mathrm{~h}$ [10]. The mechanism of bystander IFN- $\gamma$ activation depends on pro-inflammatory cytokines, mainly IL-12 and IL-18 [14].

Dengue viral infection is the cause of dengue fever (DF) and the more severe dengue hemorrhagic fever (DHF) [15]. Secondary infection by dengue virus of different serotypes to the primary infection in children aged less than 15 years is significantly associated with severe DHF $[16,17]$. Previous studies have revealed that a storm of pro-inflammatory cytokines is released during acute infection [18]. These observations suggest that 
bystander $\mathrm{T}$ cell activation might possibly occur in dengue infection.

In this study, we aimed to investigate the existence of bystander $\mathrm{T}$ cell activation in healthy children living in endemic areas who might be vulnerable to reinfection with dengue virus and at risk of developing DHF [16]. We examined IFN- $\gamma$ production, which is the established indicator for bystander $\mathrm{T}$ cell activation [10], after restimulating with inactivated dengue viral antigens in vitro. Bystander $\mathrm{T}$ cell activity was demonstrated by resistance to cyclosporin A (CsA), which is a substance known to inhibit $\mathrm{T}$ cell activation via the TCR-dependent pathway $[9,19,20]$ In addition, we described the kinetics of bystander $\mathrm{T}$ cells and cytokines involved in IFN$\gamma$-derived $\mathrm{T}$ cell activation. The description of immune profiles in this study highlights bystander activation in natural DV infection of healthy people in an endemic area and emphasizes that the immune responses to dengue virus are more complex than anticipated.

\section{Results}

Healthy Thai schoolchildren could produce IFN- $\gamma$ in response to inactivated dengue virus serotype 2 in vitro IFN- $\gamma$ was selected for determination as a marker of bystander $\mathrm{T}$ cell function in this study. The mechanisms of IFN- $\gamma$ production, triggered via TCR-dependent or independent pathways, were investigated by treatment with CsA, which is known to inhibit $\mathrm{T}$ cells via a TCRdependent pathway. Blood samples from 55 healthy Thai schoolchildren aged 13-14 years were co-cultured with control stimulators (medium, phytohemagglutinin (PHA) and a combination of IL-12 plus IL-15 cytokines) or Den2 in the absence or presence of CsA for $48 \mathrm{~h}$. The cultured supernatants were assayed for IFN- $\gamma$ by sandwich ELISA.

The positive control stimulators induced significantly higher IFN- $\gamma$ than the medium control (Figure 1A). In this study, the reduction of IFN- $\gamma$ levels (as inhibited by CsA) was defined as CsA sensitive or IFN- $\gamma$ triggered via the TCR-dependent pathway, and CsA resistant levels were defined as IFN- $\gamma$ triggered via the TCR-independent pathway. As expected, in the control stimulation, IFN- $\gamma$ induced by PHA, but not IL-12 plus IL-15, was significantly inhibited by CsA treatment $(P<0.001$, Mann Whitney test) indicating that CsA sufficiently inhibited IFN- $\gamma$ triggering via the TCR-dependent but not the cytokine receptor dependent pathway. Interestingly, IFN- $\gamma$ induced by Den 2 stimulation was also significantly inhibited by CsA $(P<0.001$, Mann Whitney test). Moreover, the remaining IFN- $\gamma$ levels after adding CsA were also significantly higher than medium plus CsA control $(P<0.001$, Mann Whitney test).

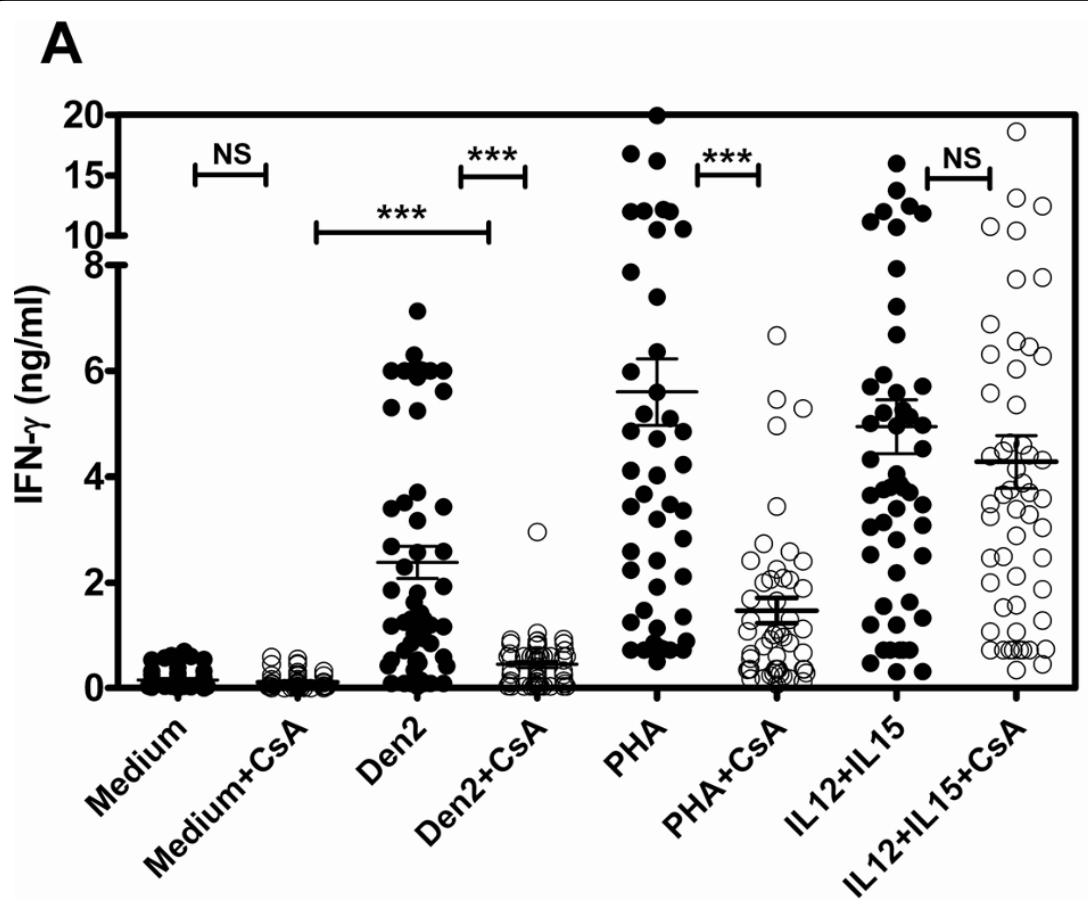

B

Figure 1 IFN- $\gamma$ induction by inactivated dengue virus serotype 2 of $\mathbf{5 5}$ healthy Thai children aged 13-14 years. Whole blood samples containing $9 \times 10^{5}$ lymphocytes $/ \mathrm{ml}$ were co-cultured with medium alone, Den2, PHA and IL-12 plus IL-15 in the presence or absence of $0.3 \mu \mathrm{g} /$ $\mathrm{ml}$ cyclosporin $\mathrm{A}$ (CSA) for $48 \mathrm{~h}$. The cultured supernatants were assayed for IFN- $\gamma$ by sandwich ELISA (A). Percentages of IFN- $\gamma$ inhibition as calculated by CsA treatment (B). ${ }^{* * *}$ represents the statistically significant difference between the two groups $(P<0.0001$, Mann Whitney test; NS represents non significant). 
Inhibition by CsA treatment in response to Den2, PHA and IL-12 plus IL-15 stimulation was $71.2 \pm 2.9 \%$ (mean $\pm \mathrm{SE}$ ), $73.2 \pm 2.0 \%$ and $12.1 \pm 2.7 \%$, respectively (Figure 1B). These results implied that IFN- $\gamma$ induction by Den 2 was mainly activated by the TCR-dependent pathway (approximately 70\%) and to a lesser degree by TCR-independent signaling (approximately $30 \%$ ).

To validate whether CsA does indeed inhibit all TCR-stimulated IFN- $\gamma$ activation, a MHC class Irestricted $\mathrm{T}$ cell epitope control of pooled peptides (CEF) of cytomegalovirus, Epstein Barr virus and influenza virus (Mabtech, $A B$, Sweden) was included in a small study with five whole blood samples from healthy school children stimulated with medium control, Den2, PHA and CEF in the presence or absence of $0.3 \mu \mathrm{g} / \mathrm{ml}$ of CsA. The results clearly showed that CsA could completely inhibit IFN- $\gamma$ induction by CEF stimulation, but it partially inhibited IFN- $\gamma$ induced by Den2. These results confirmed that CsA could inhibit all IFN- $\gamma$ production from TCR-dependent activation (See Additional file 1, Figure S1).

Moreover, we have previously titrated CsA concentration to test the ability of IFN- $\gamma$ inhibition. IFN- $\gamma$ induced by PHA, which is the strongest IFN- $\gamma$ stimulator, was inhibited by CsA in a dose-dependent manner and maximum inhibition occurred at $0.3 \mu \mathrm{g} / \mathrm{ml}$ of CsA and remained constant at higher doses. This effect could be detected at time points 4 and $42 \mathrm{~h}$ after incubation (See Additional file 1, Figure S2). These results revealed that CsA at this optimal concentration was able to inhibit $\mathrm{T}$ activation, via TCR-dependent activation, in both polyclonal and antigen-specific $\mathrm{T}$ cell activation.

\section{Identification of IFN- $\gamma^{+}$cells that responded to Den2}

To identify the types of immune cells that responded to dengue virus in the presence or absence of CsA, the intracellular sources of IFN- $\gamma$ were characterized by four-color flow cytometry. Eighteen children who had strong IFN- $\gamma$ responsiveness were followed up to determine the IFN- $\gamma$ producing cells. The collected whole blood samples containing $9 \times 10^{5}$ lymphocytes $/ \mathrm{ml}$ were co-cultured with medium and $18 \mathrm{HA}$ (hemagglutination) units Den2 for $24 \mathrm{~h}$ in the absence or presence of CsA prior to cell staining.

In flow cytometric analysis, total cell populations were analyzed by side scatter and forward scatter plotting. Then, the small lymphocyte population was first gated and shown as region R1. Total IFN- $\gamma^{+}$cells were then gated and shown as region R3 (Figure 2A). The types of IFN $-\gamma^{+}$cells were then analyzed by the combination of tri-CD3, FITC-CD8 and PE-CD4 or PE-CD56 and compared in the presence and absence of CsA (Figure 2B).

The results revealed that Den2 stimulation induced total $\% \mathrm{IFN}-\gamma^{+}$cells significantly higher than medium controls, and approximately 43\% (43.2 \pm 6.0$)$ were inhibited by CsA (data not shown). Adding CsA resulted in the reduction of total \%IFN- $\gamma+$ cells, and the proportions of IFN $-\gamma^{+}$lymphocyte subsets were slightly changed (none statistically significant) by the decrease of natural killer (NK) and increase of T cells. Moreover, the results clearly demonstrated that some $\mathrm{CD} 4^{+}$and $\mathrm{CD} 8^{+} \mathrm{T}$ cells resisted the effect of $\mathrm{CsA}$, suggesting that dengue virus induces bystander $\mathrm{T}$ cell activation in vitro (Figure 2B).

The IFN- $\gamma$ producing immune cell types in response to Den2 stimulation consist of NK cells (mean \pm SE $=$ $55.2 \pm 3.3 \%), \mathrm{CD}^{+} \mathrm{T}(24.5 \pm 3.3 \%)$ and $\mathrm{CD}^{+} \mathrm{T}(17.9 \pm$ $1.5 \%)$ cells, respectively. Interestingly, the distribution of CsA resistant or bystander $\mathrm{CD} 4^{+} \mathrm{T}$ cells ranged from 10 to $59 \%$ (mean $\pm \mathrm{SE}=26.9 \pm 3.1 \%$ ) and $\mathrm{CD} 8^{+} \mathrm{T}$ cells ranged from 7 to $39 \%(20.3 \pm 2.1 \%)$, respectively (Figure $2 \mathrm{C})$. Of note, due to the shortage of blood samples in this experiment, only 2 of 18 blood samples were studied in the presence of CsA and stained for NK cells. These results indicated that bystander (both $\mathrm{CD} 4^{+}$and $\mathrm{CD}^{+}$) $\mathrm{T}$ cells and NK cells could contribute equally to the production of IFN- $\gamma$ in responses to dengue virus in vitro.

The additional analysis of NK cell surface markers clearly demonstrated that CD3-CD56+CD16+ cells were also sources of IFN- $\gamma(23.9 \pm 7.1 \%$ of NK cells) (data not shown).

\section{Kinetics of bystander T and NK cell activation}

To describe characteristic of activated bystander T cells, the kinetics of IFN $-\gamma$ production of those bystander $\mathrm{T}$ cells were compared with innate NK cells and activated specific $\mathrm{T}$ cells. Blood samples from seven schoolchildren were studied after 12,24 and $36 \mathrm{~h}$ stimulation (details as described in the above section). The results revealed that IFN $-\gamma^{+}$cells could be detected as early as $12 \mathrm{~h}$ and most of seven samples showed similar kinetics of bystander $\mathrm{CD}^{+}, \mathrm{CD}^{+} \mathrm{T}$ and NK cells (Figure $3 \mathrm{~A}$ ). One particular sample (hC004) showed a CD8+T predominant response with almost no $\mathrm{CD} 4^{+} \mathrm{T}$ cells. These results demonstrated the similar characteristics of bystander $\mathrm{T}$ cells in producing IFN- $\gamma$ in addition to NK cells in response to dengue virus. In contrast to bystander $\mathrm{CD} 4^{+}$and $\mathrm{CD}^{+}{ }^{+}$cells, specific $\mathrm{CD} 4^{+}$and/or CD8 ${ }^{+} \mathrm{T}$ cells, were not detected as early as $12 \mathrm{~h}$ in five of seven samples (hC004, hC022, hC031, hC038 and hC084) (Figure 3B). The proportion of bystander and specific $\mathrm{T}$ cells from 18 samples, however, was equal after $24 \mathrm{~h}$ culture (Figure 3C). Taken together, these results indicated that innate immune cells (NK cells and bystander $\mathrm{T}$ cells) were rapidly induced in the early response and were followed by specific $\mathrm{T}$ cells to produce IFN- $\gamma$ in response to dengue virus. 


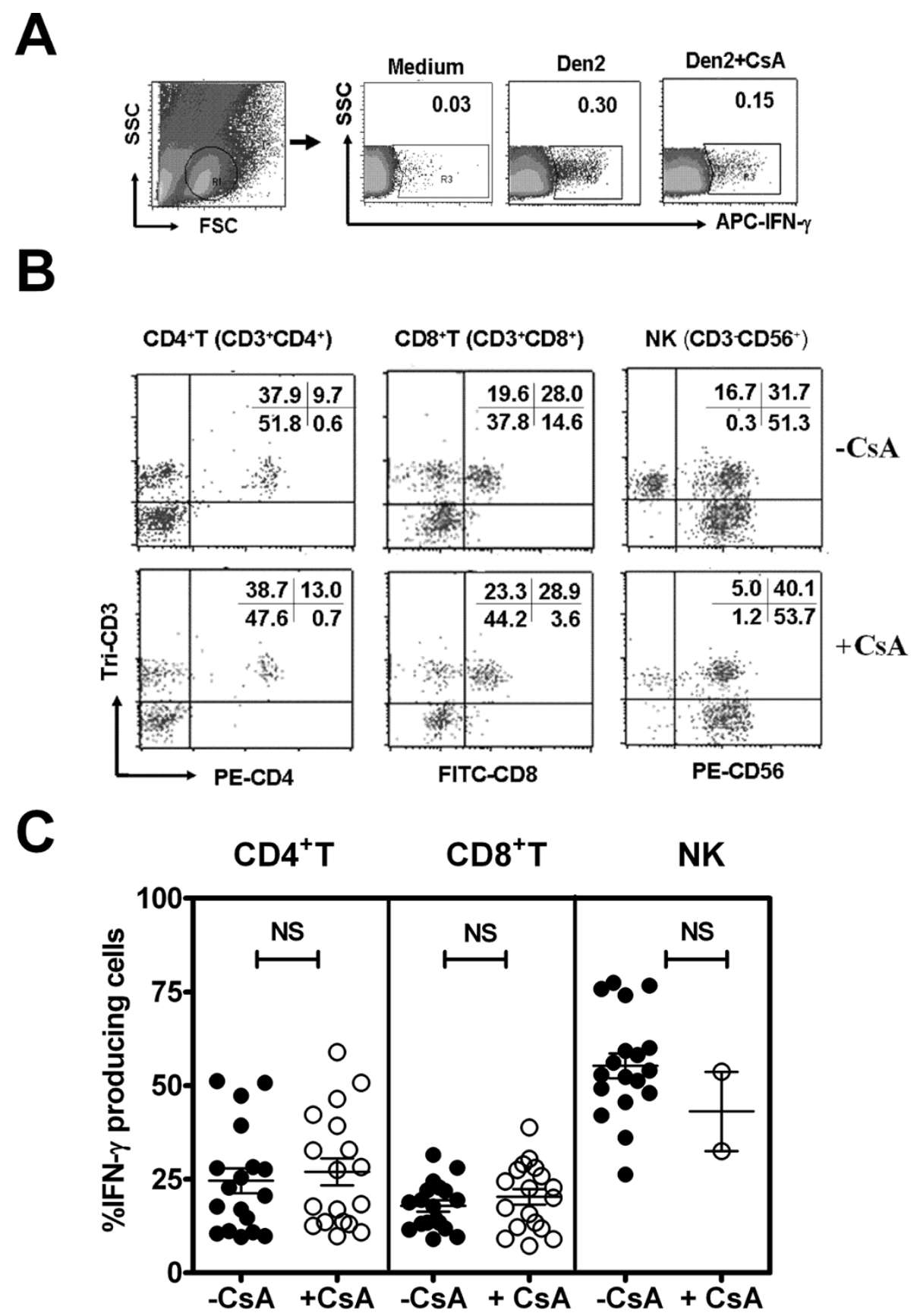

Figure 2 Identification of IFN- $\boldsymbol{\gamma}$ producing cells using flow cytometry. Cells cultured with medium, Den2 with or without CsA at $24 \mathrm{~h}$ were stained with tri-CD3, FITC-CD8 and PE-CD4 or PE-CD56 and APC-IFN- $\boldsymbol{\gamma}$. Gating profile of small lymphocyte (R1) and IFN- $\boldsymbol{\gamma}^{+}$cell (R3) from one representative sample (A). Gated IFN- $\gamma$ producing cells were analyzed with cell surface marker profiles (B). The distribution of IFN- $\gamma$ producing $\mathrm{CD}^{+}, \mathrm{CD}^{+} \mathrm{T}$ and NK cells from 18 samples were plotted and compared between absence (-CsA) and presence of CSA (+CSA) (C) by Mann Whitney test (NS represents non significant).

IL-12-dependent pathway mediated T cell to produce IFN- $\gamma$ Previously, proinflammatory cytokines such as IL-12, IL-15 and IL-18 have been reported to elicit bystander $\mathrm{T}$ cells to produce IFN- $\gamma[10,14]$. To confirm that anticytokine neutralizing antibodies are, in fact, capable of inhibiting the cytokines at the concentrations used, the whole blood samples from healthy donors were treated with three-fold serial concentration of anti-IL-12, antiIL-15 and anti-IL-18 (at $0.3,1$ and $3 \mu \mathrm{g} / \mathrm{ml}$, respectively) for 15 minutes before stimulation with heat-inactivated Burkholderia pseudomallei, a strong bystander or cytokine-dependent $\mathrm{T}$ cell inducer as shown previously by 


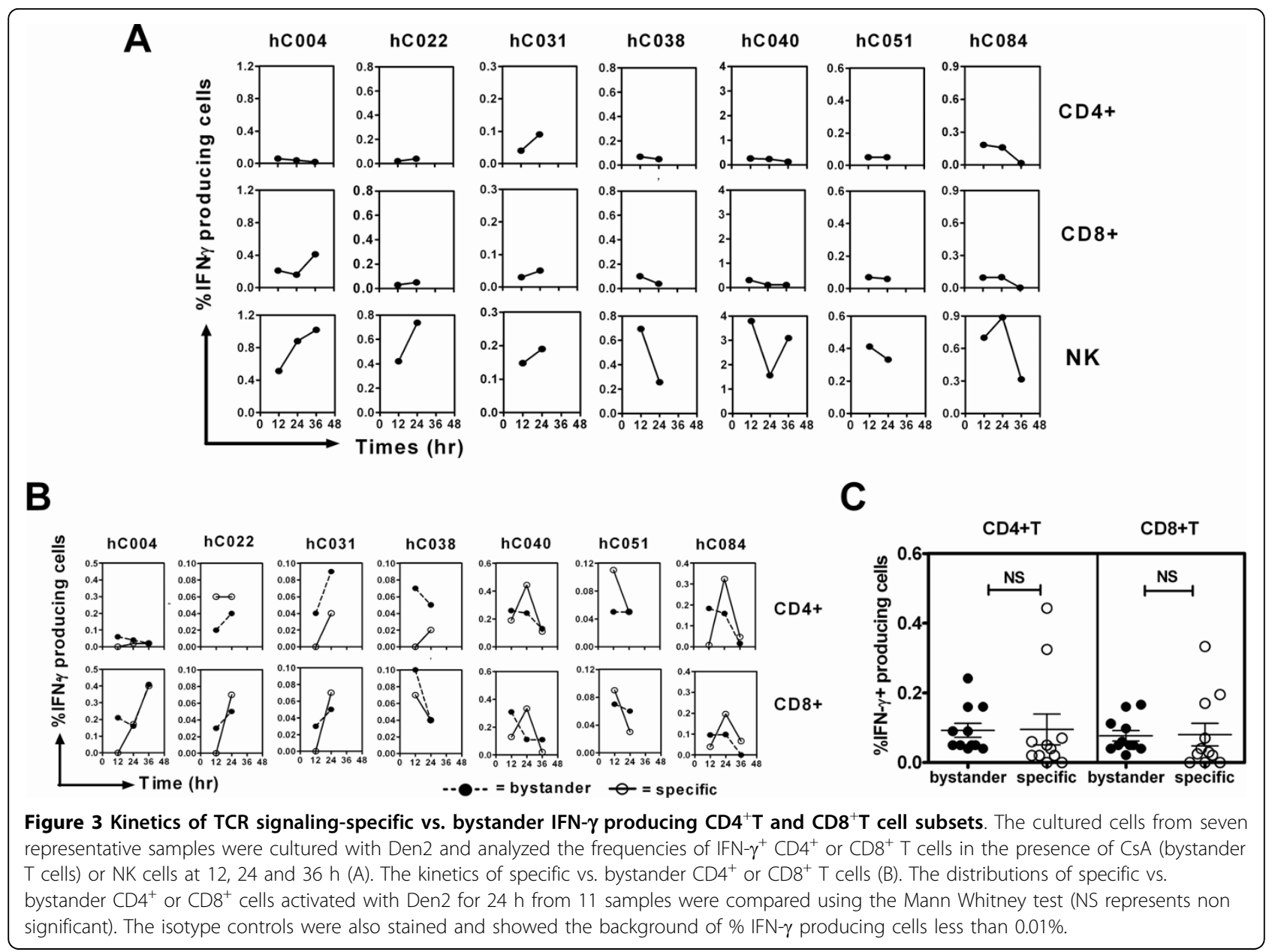

our group. After $48 \mathrm{~h}$, the cultured supernatants were harvested and examined for IFN- $\gamma$ level by ELISA. The results showed that all three anti-cytokine neutralizing antibodies could decrease IFN- $\gamma$ induction by B. pseudomalle $i$ in a dose-dependent manner. Therefore, the concentration of these antibodies at $1 \mu \mathrm{g} / \mathrm{ml}$ was used in the following Den2 experiments (See Additional file 1, Figure S3).

To investigate these cytokines in IFN- $\boldsymbol{\gamma}$ production in response to dengue virus, the effects of neutralizing antibodies to these cytokines were investigated. Eleven whole blood samples from healthy adult blood donors were studied by adding neutralizing monoclonal antibodies to human IL-12, IL-15 and IL-18, and testing the culture supernatants for IFN- $\gamma$ by ELISA. The results revealed that adding anti-IL-12, but not anti-IL-15 nor anti-IL-18, resulted in the statistically significant reduction of IFN- $\gamma$ in response to dengue virus stimulation. These results revealed that IFN- $\gamma$ was mainly activated by the IL-12-dependent pathway. Additionally, IFN- $\gamma$ was completely inhibited by the combination of anti-IL12 and CsA treatment suggesting synergistic effects of
IL-12-dependent and TCR-dependent pathways (Figure 4A). Three representative donors were then selected to characterize the intracellular sources of IFN- $\gamma$ by flow cytometry using the protocol described above. The results showed that, as for the blood samples from children, the major IFN- $\gamma$ producing cells were NK, $\mathrm{CD}_{4}^{+} \mathrm{T}$ and $\mathrm{CD} 8^{+} \mathrm{T}$, respectively (data not shown). Additionally, the distribution of bystander vs. specific $\mathrm{CD} 4^{+}$or $\mathrm{CD} 8$ ${ }^{+} \mathrm{T}$ cells was not significantly different (Figure 4B). To determine effect of neutralizing monoclonal antibodies on the IFN- $\gamma$ producing subpopulation, two representative samples were studied. Results showed that anti-IL-12 and CsA could decrease IFN- $\gamma$ producing cells derived from both $\mathrm{CD} 4^{+}$and $\mathrm{CD} 8^{+} \mathrm{T}$ cells and the synergistic effect of the two pathways was also observed. $\mathrm{CD} 4^{+} \mathrm{T}$ cells were equally sensitive to anti-IL-12 and CsA whereas $\mathrm{CD}^{+} \mathrm{T}$ cells were less sensitive to anti-IL12 than CsA (Figure 4C). In contrast to $\mathrm{T}$ cells, NK cells were more sensitive to anti-IL-12 than CsA, as suggested in one case where NK cell markers were included and approximately $34 \%$ of IFN- $\gamma$ production from NK cells was inhibited by CsA, while anti-IL-12 was able to 


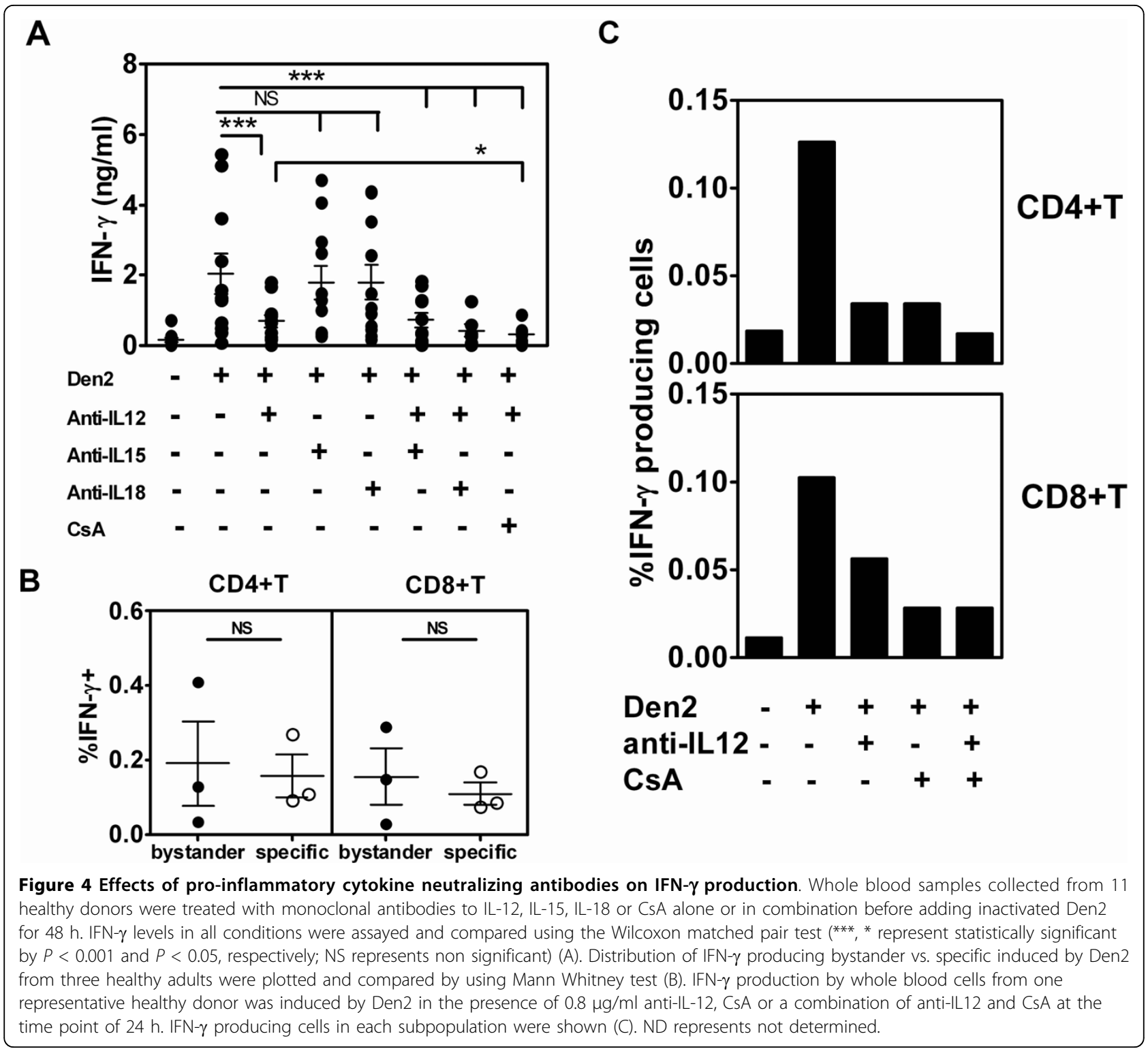

inhibit IFN- $\gamma$ production up to $75 \%$. These results confirmed that there were bystander $\mathrm{T}$ cells that could produce IFN- $\gamma$ via an IL-12-dependent pathway in response to dengue infection.

\section{Discussion}

In this study we first demonstrated that healthy Thai schoolchildren could produce IFN- $\gamma$ in response to dengue virus serotype 2 , which is the predominant serotype and the major cause of DHF [16]. Then, we highlighted the major finding that bystander $\mathrm{CD} 4^{+} \mathrm{T}$ and $\mathrm{CD} 8^{+}$ $\mathrm{T}$ cells responding to dengue virus could account for approximately $50 \%$ of immune components producing IFN- $\gamma$ via the TCR-independent pathway as demonstrated by their resistance to CsA (See Additional file 1,
Figure S4 for the details of calculation). The contribution of these innate and/or adaptive immune components was demonstrated by the study of time kinetics, and the results clearly showed that the kinetics of bystander $\mathrm{T}$ cells were similar to those of NK cells and, in most cases, were in contrast to specific $\mathrm{T}$ cells. These results suggest a key function of innate immunity composed of NK and bystander $\mathrm{T}$ cells in rapid responses to control early dengue virus infection.

Determination of bystander T cell activation by using CsA treatment has been previously used by our group and others [9,21]. Moreover, the studies using neutralizing antibodies for IL-12, IL-15, IL-18 [14,19], or blocking antibodies for their receptors $[21,22]$ has confirmed that bystander T cells and NK cells could be activated 
by these cytokines. Our studies clearly demonstrated that there were $\mathrm{CD} 4^{+}$and $\mathrm{CD} 8^{+} \mathrm{T}$ cells resistant to CsA treatment in healthy children's blood samples responding to dengue virus. These bystander $\mathrm{T}$ cells were strongly activated via an IL-12-dependent pathway as demonstrated by neutralization of anti-IL-12 but not anti-IL-15 or anti-IL-18. Additionally, no synergistic action between IL-12 and IL-15 or IL-18 could be observed suggesting that the activation of $\mathrm{T}$ cells via IL12 alone was sufficient to produce IFN- $\gamma$. Paganin et al. have reported that IL-12 alone primes both $\mathrm{CD}^{+}$and $\mathrm{CD}^{+} \mathrm{T}$ clones for high IFN- $\gamma$ production, and the principle mechanism is the ability to prime $\mathrm{T}$ cells during Th1 clonal expansion [23]. In addition to IL-12 alone, $\mathrm{T}$ cells also secrete IFN- $\gamma$ in a TCR-independent manner after stimulation with the pro-inflammatory cytokines; IL-12, IL-15 and IL-18 or the synergistic actions of IL12 and either IL-18 or IL-15 [24,25]. However, CsA could inhibit some IFN- $\gamma$ producing NK cells. This unexpected effect of CsA on NK cells has also been demonstrated by Wang et al. The co-culture of peripheral blood NK cells subpopulations with CsA can decrease proliferation of CD56 ${ }^{\mathrm{dim}} \mathrm{NK}$ cells (CD3 ${ }^{-} \mathrm{CD} 56$ ${ }^{+} \mathrm{CD} 16^{+}$) but not $\mathrm{CD} 56^{\text {bright }} \mathrm{NK}$ cells (CD3 ${ }^{-} \mathrm{CD} 56$ $\left.{ }^{+} \mathrm{CD} 16^{-}\right)$[26]. Our studies have shown that CD56 ${ }^{\mathrm{dim}} \mathrm{NK}$ cells produced IFN- $\gamma$ in cell culture. Therefore, CsA might affect this NK cell subpopulation.

In addition, $\mathrm{CD} 16^{-} \mathrm{CD} 56^{+} \mathrm{NK}$ cells, $\mathrm{CD} 3^{-} \mathrm{CD} 56^{+} \mathrm{CD} 16^{+}$ $\mathrm{NK}$ cells, $\mathrm{CD}^{+}{ }^{+} \mathrm{CD} 56^{+} \mathrm{NKT}$ cells, $\mathrm{CD} 3^{-} \mathrm{CD}^{+}$cells and $\mathrm{CD} 3^{-} \mathrm{CD} 4^{+}$cells were also found to produce IFN- $\gamma$ in this study. Azeredo et al., have shown the increase of $\mathrm{CD}^{-} \mathrm{CD} 56^{+} \mathrm{CD} 16^{+}$(NK cells), $\mathrm{CD}^{+} \mathrm{CD} 56^{+}\left(\mathrm{CD} 56^{+} \mathrm{T}\right.$ cells) during acute dengue infection [27]. Our findings supported the idea that those cells could respond by IFN- $\gamma$ production against dengue virus at least in an IL12-dependent manner. It has also been reported that NK cells control early dengue virus infection via antibody-dependent cellular cytotoxicity [28]. In light of recent evidence, the barrier between innate and adaptive immunity seems to be blurred [29]; our study offers the possibility of investigating this novel concept of host immunity in dengue infection.

One study of immune responses of volunteers who had received the live attenuated monovalent dengue vaccines reported that restimulating memory $\mathrm{CD} 4^{+} \mathrm{T}$ cells in peripheral blood mononuclear cells with homologous inactivated dengue serotype resulted in the highest IFN- $\gamma$ production whereas stimulation with heterologous serotypes resulted in the alteration of IFN$\gamma$ to TNF-alpha production [30]. Another study from the same group reported that dengue virus-reactive $\mathrm{CD} 8^{+} \mathrm{T}$ cells showed differences in both proliferation and cytokine production responding to heterologous viral serotypes. Restimulation of these $\mathrm{CD} 8^{+} \mathrm{T}$ cells with dengue serotype 3 variant of NS4b epitope 2423 and dengue 2 variant of NS4a epitope 2148 resulted in the greatest cytokine production [31]. Moreover, Mongkolsapaya et al. have reported that cross-reactive dengue specific $\mathrm{CD}^{+} \mathrm{T}$ cells seemed to show suboptimal degranulation but also high IFN- $\gamma$ and TNF-alpha production [1]. These results implied that specific $\mathrm{T}$ cell responses might lead to high levels of IFN- $\gamma$ production whereas cross-reactive $\mathrm{T}$ cell responses alter cytokine profiles and contribute to disease severity. In respect of our studies, IFN- $\gamma$ induced by Den1, 3 and 4 were also investigated. However, the IFN- $\gamma$ induced by these antigens was much less than Den2 stimulation. These results might reflect the activation of Den2-specific $\mathrm{T}$ cells. However, relative contribution of specific vs. cross-reactive vs. bystander $\mathrm{T}$ cells to immunopathogenesis of dengue infection requires further investigation.

Nevertheless, the pre-existing immunity which protects or increases disease severity during secondary infection has not been well defined. The previous prospective study of Thai schoolchildren has revealed that the higher degree of activation of pre-existing IFN- $\gamma$ responding to any of the four serotypes correlated with the subsequent hospitalization of children aged 7 10 years [5]. The IFN- $\gamma$ induction in our study generally showed higher levels than the previous study of Mangada et al.; this could be due to the fact that all cellular functions in our study were performed in whole blood samples freshly collected within $4 \mathrm{~h}$ to avoid any decreased activities by the cryopreservation process of frozen samples. In addition, among 55 healthy school children in this study, 11 were seronegative and 44 were seropositive for IgG anti-dengue antibody. However, bystander IFN- $\gamma$ production from these two populations was not different. Thus the degree of total or bystander IFN- $\gamma$ production may be further studied as a potential predictor for DHF of sufficient severity to require hospitalization.

This study focused on bystander IFN- $\gamma$ production in responses to inactivated dengue viral antigens in vitro using the same dengue viral preparation as for currently available commercial antibody assays. Unfortunately, a non-infected control from the same commercial source was not available for confirmation of antigen specific activation. Since it was prepared from suckling mouse brain, no animal laboratories could provide the control brain tissues without a proper license. Thus, IFN- $\gamma$ induced by another source of inactivated antigens, cultured supernatants of C6/36 mosquito cells infected with dengue viral serotype 2 (16681 strain), was compared instead (See Additional file 1, Figure S5). Inactivated culture supernatants of mock-infected C6/36 cell lines showed no IFN- $\gamma$ induction and the inactivated supernatants of Den2-infected C6/36 cells could 
stimulate cells to produce IFN- $\gamma$ to higher levels than the medium control. Much less IFN- $\gamma$ was induced by inactivated cultured supernatants than by mouse extracts. However, regression analysis of IFN- $\gamma$ induced by two antigens showed that bystander but not specific IFN- $\gamma$ levels were correlated (See Additional file 1, Figure S6). These results strongly supported the observation that dengue antigens could trigger bystander IFN- $\gamma$ production in vitro.

\section{Conclusions}

We have defined the bystander activation of $\mathrm{T}$ cells in responses to dengue infection, mediated by IL-12dependent pathways existing in healthy Thai schoolchildren. These bystander $\mathrm{T}$ cells play a major contribute to the IFN- $\gamma$ production in response to dengue virus in vitro. These immunological responses may be involved in immunopathogenesis of dengue hemorrhagic fever and provide basic information on immune cell profiles in children living in endemic areas with potential use for dengue vaccine development.

\section{Methods}

\section{Subjects}

The subjects were 55 healthy schoolchildren (17 females, 38 males, and aged 13-14 years) who were studying at the Secondary School, Phu Wat Pittayakom, Ubonrat District, Khon Kaen Province, Thailand. Blood samples were collected from each child to screen for IFN- $\gamma$ production using ELISA. Follow-up blood samples were collected from 18 children for characterization of intracellular IFN- $\gamma$ sources by fourcolor flow cytometry. None of the children had had any febrile episode in the seven days prior to collection of the whole blood samples. Twelve children had previously been hospitalized because of dengue infection. The protocol for the collection of whole blood samples has been reviewed and approved by Khon Kaen University Ethics Committee for Human Research (project number HE470510). All children and their parents signed the informed consent form before whole blood collection and the data in the consent forms were not disclosed. Additionally, 11 blood samples were collected from healthy adults to study cytokine neutralization. The samples were processed using the same protocol.

\section{Stimulators}

\section{Control stimulators}

The negative control was cell culture medium $(10 \%$ fetal bovine serum in RPMI). The positive controls for IFN- $\gamma$ activation via the TCR-dependent pathway and cytokine activation were $2.5 \mu \mathrm{g} / \mathrm{ml}$ PHA (Roche, USA) and $0.1 \mathrm{ng} / \mathrm{ml}$ IL-12 plus IL-15, respectively.

\section{Dengue viral antigens}

Lyophilized mouse brain extracts containing dengue viral antigen serotype 1 (Den1, Hawaii strain), Den2 ( $\mathrm{Tr}$ 1751 strain), Den3 (H 87 strain) and Den4 (H 241 strain) were purchased from the Department of Medical Science, Ministry of Public Health, Thailand for use in this study. These antigens were prepared by sucrose acetone extraction of mouse brains infected by dengue serotype 1-4 [32]. Preliminary studies revealed that 18 HA units of Den 2 could induce the highest IFN- $\gamma$ production compared to other serotypes. Thus this optimal antigen concentration was used in all experiments.

\section{Whole blood culture assay for IFN- $\gamma$ induction}

Whole blood samples $(18 \mathrm{ml})$ were collected from subjects in heparinized tubes. Complete blood cells counts were performed using an automatic analyzer (Sysmex SF-3000, Germany). Lymphocyte numbers were adjusted to $9 \times 10^{5}$ cells $/ \mathrm{ml}$ by diluting with culture medium (RPMI with $10 \%$ fetal bovine serum). The cells were freshly co-cultured with stimulators in 96-well culture plates and incubated in $5 \% \mathrm{CO}_{2}$ at $37^{\circ} \mathrm{C}$ for $12,24,36$, and $48 \mathrm{~h}$, or as required.

To distinguish the IFN- $\gamma$ production induced by TCRdependent and TCR-independent pathways, CsA (Sigma, USA), a substance known to inhibit $\mathrm{T}$ cell activation via the TCR-dependent pathway, was added at $0.3 \mu \mathrm{g} / \mathrm{ml}$ which was the optimal concentration to inhibit IFN- $\gamma$ production induced by PHA and then IFN- $\gamma$ levels was compared in presence and absence of CsA $[19,20]$.

For the cytokine neutralization assay, adjusted blood samples were treated with $1 \mathrm{pg} / \mathrm{ml}$ of cytokine neutralizing monoclonal antibodies composed of anti-human IL12 (clone 24910.1, R\&D system, USA), anti-IL-15 (clone34598.11, R\&D system, USA), and anti-human IL18 (clone 125-2H, Medical \& Biological Laboratories, Japan) for 15 min before adding 18 HA units Den2. The cultured supernatants were harvested and kept at $-20^{\circ} \mathrm{C}$ prior to IFN- $\gamma$ detection by sandwich ELISA (BD OptEIA $^{\text {su }}$ set Human IFN- $\gamma$, BD Bioscience, USA) as per manufacturer's protocol. The standard curve was linear up to $300 \mathrm{pg} / \mathrm{ml}$ and the detection limit was $18.8 \mathrm{pg} / \mathrm{ml}$. Any cultured supernatants that showed an optical density higher than $300 \mathrm{pg} / \mathrm{ml}$ were diluted, retested and the IFN $-\gamma$ concentration was estimated by multiplying with the dilution factor.

\section{Intracellular IFN- $\boldsymbol{\gamma}$ vs. cell surface markers staining and flow cytometric analysis}

Whole blood samples containing $9 \times 10^{5}$ lymphocytes/ $\mathrm{ml}$ were co-cultured with stimulators in FACS tubes (BD Bioscience) and $10 \mu \mathrm{g} / \mathrm{ml}$ brefeldin A (Sigma) was added for the last $3 \mathrm{~h}$. Then, red blood cells in cultured samples were lysed by lysing solution (BD Bioscience, 
USA), and the samples washed once with $1 \%$ FCS-PBS, and Fc receptors were blocked with anti-CD16 for $30 \mathrm{~min}$. Cultured cells were washed once and stained for cell surface markers using tri-color labeled anti-CD3 (Caltag Laboratories, USA) and PE-labeled anti-CD4 or PE-labeled anti-CD8 or PE-labeled-CD56 (PharMingen, USA) and FITC-labeled anti-CD4 or FITC-labeled antiCD8 or FITC-labeled anti-CD16 (Caltag Laboratories). Isotype-matched immunoglobulin controls were included in each analysis. Staining of cell surface markers was performed for $30 \mathrm{~min}$ at $4^{\circ} \mathrm{C}$, and the stained cells were washed twice in cold 1\% FCS-PBS and fixed with $10 \%$ paraformaldehyde-PBS at $4^{\circ} \mathrm{C}$ for $15 \mathrm{~min}$. Fixation was followed by permeabilization with $1 \%$ FCSPBS, $0.1 \%$ saponin (Sigma) and $0.1 \%$ sodium azide (Sigma). Staining of intracellular IFN- $\gamma$ was performed by incubating permeabilized cells with $1 \mu \mathrm{g}$ /tube APClabeled anti-human IFN- $\gamma$ (Caltag Laboratories) in incubation buffer (1\% FBS, $0.1 \%$ saponin and $0.1 \%$ sodium azide in PBS) at room temperature for $30 \mathrm{~min}$. The stained cells were washed once and resuspended in $10 \%$ paraformaldehyde-PBS. Analysis was performed by FACSCalibur flow cytometer and CELLQuest software (BD Bioscience).

\section{Statistical analysis}

The Mann-Whitney test and the Wilcoxon signed rank test for comparison and linear regression for correlation were performed using Graph Pad Prism software version 5 (GraphPad, San Diego, USA). A $P$-value less than 0.05 was considered statistically significant.

\section{Additional material}

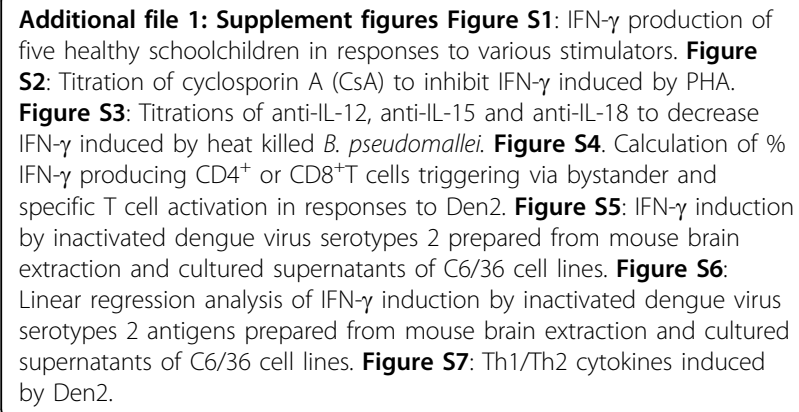

\section{Abbreviations}

Den: dengue viral antigen; Den 1, 2, 3 and 4: dengue viral serotype 1, 2, 3 and 4; IFN- $\gamma$ : interferon-gamma; TCR: T cell receptor; CsA: cyclosporin A; IL: interleukin; DHF: dengue hemorrhagic fever.

\section{Acknowledgements}

This work was supported by Thailand Tropical Diseases Research Program (ID 02-2-DEN-05-061) from the National Center for Genetic Engineering and Biotechnology (BIOTEC), Thailand. DS was supported by CDML, Khon Kaen
University, Thailand. We thank the staff at Phu Wat Pittakom School and Khon Kaen Hospital; healthy children and their guardians for permission to collect whole blood samples; Ms Surapee Anantapreecha, Department of Medical Science, Ministry of Public Health, Thailand, for providing inactivated dengue antigens; Ms Patcharaporn Tippayawat for providing help on flow cytometry; Drs Sirijit Vasanawathana and Nicha Charoensri for their suggestions; Drs Manabu Ato and D. Huw Davies for their critical comments and reviewing the manuscript and Ms Vicki Harley for her editorial help in preparing this manuscript.

\section{Authors' contributions}

DS carried out the cellular studies and draft the manuscript. AR and CL participated in the design of the study. GL conceived of the study and participated in its design and coordination. All authors read and approved the final manuscript.

Received: 29 August 2009 Accepted: 20 September 2010 Published: 20 September 2010

\section{References}

1. Mongkolsapaya J, Duangchinda T, Dejnirattisai W, Vasanawathana S, Avirutnan P, Jairungsri A, Khemnu N, Tangthawornchaikul N, Chotiyarnwong P, Sae-Jang K, Koch M, Jones Y, McMichael A, Xu X, Malasit $P$, Screaton $G$ : $T$ cell responses in dengue hemorrhagic fever: are cross-reactive T cells suboptimal? J Immunol 2006, 176:3821-3829.

2. Kurane I, Innis BL, Nisalak A, Hoke C, Nimmannitya S, Meager A, Ennis FA: Human T cell responses to dengue virus antigens: Proliferative responses and interferon gamma production. J Clin Invest 1989, 83:506-513.

3. Libraty DH, Endy TP, Houng HS, Green S, Kalayanarooj S, Suntayakorn S, Chansiriwongs W, Vaughn DW, Nisalak A, Ennis FA, Rothman AL: Differing influences of virus burden and immune activation on disease severity in secondary dengue-3 virus infections. J Infect Dis 2002, 185:1213-1221.

4. Kurane I, Innis BL, Nimmannitya S, Nisalak A, Meager A, Janus J, Ennis FA: Activation of T lymphocytes in dengue virus infections: High levels of soluble interleukin 2 receptor, soluble CD4, soluble CD8, interleukin 2, and interferon-gamma in sera of children with dengue. J Clin Invest 1991, 88:1473-1480.

5. Mangada MM, Endy TP, Nisalak A, Chunsuttiwat S, Vaughn DW, Libraty DH, Green S, Ennis FA, Rothman AL: Dengue-specific T cell responses in peripheral blood mononuclear cells obtained prior to secondary dengue virus infections in Thai schoolchildren. J Infect Dis 2002, 185:1697-1703.

6. Mathew A, Kurane I, Green S, Vaughn DW, Kalayanarooj S, Suntayakorn S, Ennis FA, Rothman AL: Impaired T cell proliferation in acute dengue infection. J Immunol 1999, 162:5609-5615.

7. Zivna I, Green S, Vaughn DW, Kalayanarooj S, Stephens HA, Chandanayingyong $D$, Nisalak A, Ennis FA, Rothman AL: T cell responses to an HLA-B*07-restricted epitope on the dengue NS3 protein correlate with disease severity. J Immunol 2002, 168:5959-5965.

8. Zhang X, Sun S, Hwang I, Tough DF, Sprent J: Potent and selective stimulation of memory-phenotype $\mathrm{CD}^{+} \mathrm{T}$ cells in vivo by IL-15. Immunity 1998, 8:591-599.

9. Deshpande S, Zheng M, Lee S, Banerjee K, Gangappa S, Kumaraguru U, Rouse BT: Bystander activation involving $\mathrm{T}$ lymphocytes in herpetic stromal keratitis. J Immunol 2001, 167:2902-2910.

10. Lertmemongkolchai G, Cai G, Hunter CA, Bancroft GJ: Bystander activation of CD8+ T cells contributes to the rapid production of IFN-gamma in response to bacterial pathogens. J Immunol 2001, 166:1097-1105.

11. Bangs SC, McMichael AJ, Xu XN: Bystander T cell activation-implications for HIV infection and other diseases. Trends Immunol 2006, 27:518-524.

12. Smeltz RB: Profound enhancement of the IL-12/IL-18 pathway of IFNgamma secretion in human CD8+ memory T cell subsets via IL-15. J Immunol 2007, 178:4786-4792.

13. Kim SK, Brehm MA, Welsh RM, Selin LK: Dynamics of memory T cell proliferation under conditions of heterologous immunity and bystander stimulation. J Immunol 2002, 169:90-98.

14. Rowland CA, Lertmemongkolchai G, Bancroft A, Haque A, Lever MS, Griffin KF, Jackson MC, Nelson M, O'Garra A, Grencis R, Bancroft GJ, Lukaszewski RA: Critical role of type 1 cytokines in controlling initial infection with Burkholderia mallei. Infect Immun 2006, 74:5333-5340. 
15. Organization WH: Dengue and Dengue Hemorrhagic Fever. Fact Sheet 2008.

16. Nisalak A, Endy TP, Nimmannitya S, Kalayanarooj S, Thisayakorn U, Scott RM, Burke DS, Hoke CH, Innis BL, Vaughn DW: Serotype-specific dengue virus circulation and dengue disease in Bangkok, Thailand from 1973 to 1999. Am J Trop Med Hyg 2003, 68:191-202.

17. Endy TP, Nisalak A, Chunsuttiwat S, Libraty DH, Green S, Rothman AL, Vaughn DW, Ennis FA: Spatial and temporal circulation of dengue virus serotypes: a prospective study of primary school children in Kamphaeng Phet, Thailand. Am J Epidemiol 2002, 156:52-59.

18. Pang T, Cardosa MJ, Guzman MG: Of cascades and perfect storms: the immunopathogenesis of dengue haemorrhagic fever-dengue shock syndrome (DHF/DSS). Immunol Cell Biol 2007, 85:43-45.

19. Okamura H, Kashiwamura S, Tsutsui H, Yoshimoto T, Nakanishi K: Regulation of interferon-gamma production by IL-12 and IL-18. Curr Opin Immunol 1998, 10:259-264.

20. Yang J, Zhu H, Murphy TL, Ouyang W, Murphy KM: IL-18-stimulated GADD45 beta required in cytokine-induced, but not TCR-induced, IFNgamma production. Nature Immunology 2001, 2:157-164.

21. Bofill M, Almirall E, McQuaid A, Pena R, Ruiz-Hernandez R, Naranjo M, Ruiz L, Clotet B, Borras FE: Differential expression of the cytokine receptors for human interleukin (IL)-12 and IL-18 on lymphocytes of both CD45RA and CD45RO phenotype from tonsils, cord and adult peripheral blood. Clin Exp Immunol 2004, 138:460-465.

22. de Arquer GR, Pena R, Cabrera C, Coma G, Ruiz-Hernandez R, Guerola R, Clotet B, Ruiz L, Este JA, Calle ML, Bofill M: Skewed expression and upregulation of the IL-12 and IL-18 receptors in resting and activated CD4 T cells from HIV-1-infected patients. J Leukoc Biol 2007, 82:72-78.

23. Paganin C, Frank I, Trinchieri G: Priming for high interferon-gamma production induced by interleukin- 12 in both $\mathrm{CD}_{4}^{+}$and $\mathrm{CD}^{+} \mathrm{T}$ cell clones from HIV-infected patients. J Clin Invest 1995, 96:1677-1682.

24. Barbulescu K, Becker C, Schlaak JF, Schmitt E, Meyer zum Buschenfelde KH, Neurath MF: IL-12 and IL-18 differentially regulate the transcriptional activity of the human IFN-gamma promoter in primary $\mathrm{CD} 4^{+} \mathrm{T}$ lymphocytes. J Immunol 1998, 160:3642-3647.

25. Liu K, Catalfamo M, Li Y, Henkart PA, Weng NP: IL-15 mimics T cell receptor crosslinking in the induction of cellular proliferation, gene expression, and cytotoxicity in $\mathrm{CD}^{+}$memory T cells. Proc Natl Acad Sci USA 2002, 99:6192-6197.

26. Wang H, Grzywacz B, Sukovich D, McCullar V, Cao Q, Lee AB, Blazar BR, Cornfield DN, Miller JS, Verneris MR: The unexpected effect of cyclosporin $A$ on $\mathrm{CD} 56^{+} \mathrm{CD} 16^{-}$and $\mathrm{CD} 56^{+} \mathrm{CD} 16^{+}$natural killer cell subpopulations. Blood 2007, 110:1530-1539.

27. Azeredo EL, De Oliveira-Pinto LM, Zagne SM, Cerqueira DI, Nogueira RM, Kubelka CF: NK cells, displaying early activation, cytotoxicity and adhesion molecules, are associated with mild dengue disease. Clinical and experimental immunology 2006, 143:345-356.

28. Laoprasopwattana K, Libraty DH, Endy TP, Nisalak A, Chunsuttiwat S, Ennis FA, Rothman AL, Green S: Antibody-dependent cellular cytotoxicity mediated by plasma obtained before secondary dengue virus infections: potential involvement in early control of viral replication. The Journal of infectious diseases 2007, 195:1108-1116.

29. Lanier $L L$, Sun JC: Do the terms innate and adaptive immunity create conceptual barriers? Nature reviews Immunology 2009, 9:302-303.

30. Mangada MM, Rothman AL: Altered cytokine responses of denguespecific $\mathrm{CD}^{+}{ }^{+} \mathrm{T}$ cells to heterologous serotypes. J Immunol 2005, $175: 2676-2683$

31. Bashyam HS, Green S, Rothman AL: Dengue virus-reactive $\mathrm{CD}^{+} \mathrm{T}$ cells display quantitative and qualitative differences in their response to variant epitopes of heterologous viral serotypes. J Immunol 2006, 176:2817-2824.

32. Innis BL, Nisalak A, Nimmannitya S, Kusalerdchariya S, Chongswasdi V, Suntayakorn S, Puttisri P, Hoke CH: An enzyme-linked immunosorbent assay to characterize dengue infections where dengue and Japanese encephalitis co-circulate. Am J Trop Med Hyg 1989, 40:418-427.

doi:10.1186/1471-2172-11-47

Cite this article as: Suwannasaen et al:: Bystander T cells in human immune responses to dengue antigens. BMC Immunology 2010 11:47.

\section{Submit your next manuscript to BioMed Central and take full advantage of:}

- Convenient online submission

- Thorough peer review

- No space constraints or color figure charges

- Immediate publication on acceptance

- Inclusion in PubMed, CAS, Scopus and Google Scholar

- Research which is freely available for redistribution

Submit your manuscript at www.biomedcentral.com/submit
Biomed Central 